\title{
Stabilization of Overweight and Obesity in Slovenian Adolescents and Increased Risk in Those Entering Non-Grammar Secondary Schools
}

\author{
Katarina Sedeja ${ }^{a}$ Lara Lusa $^{b} \quad$ Tadej Battelino $^{c} \quad$ Primoz Kotnik $^{a}$ \\ ${ }^{a}$ Department of Endocrinology, Diabetes and Metabolism, University Children's Hospital

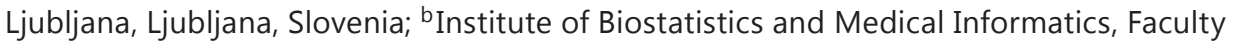 \\ of Medicine, University of Ljubljana, Ljubljana, Slovenia; ${ }^{c}$ Department of Pediatric \\ Endocrinology, Diabetes and Metabolism, UMC-University Children's Hospital, Ljubljana, \\ Slovenia
}

\author{
Key Words \\ Overweight · Obesity · Adolescent · Education · Slovenia
}

\begin{abstract}
Background/Aim: To estimate overweight and obesity prevalence trends in Slovenian adolescents entering secondary schools in the years 2004, 2009 and 2014 and differences in the prevalence between different types of secondary schools. Methods: Data from 17,538 adolescents entering secondary schools (mean age \pm standard deviation $15.4 \pm 0.5$ years) collected during obligatory medical examination in years 2004, 2009 and 2014 was analyzed. Overweight and obesity were defined using International Obesity Task Force criteria. Results: In 2004-2009 overweight and obesity prevalence increased, especially in males and stabilized thereafter (2009-2014) in both genders. It was significantly higher $(p<0.0001)$ in those attending secondary vocational and technical/professional versus grammar schools $(2009 ; 28.7$ vs. $16.8 \%$ overweight females and 31.6 vs. $22.3 \%$ overweight males; $2014: 29.7$ vs. $17.9 \%$ overweight females and 33.6 vs. $20.4 \%$ overweight males). Conclusions: Overweight and obesity prevalence in Slovenian adolescents entering secondary schools stabilized recently. Adolescents attending secondary vocational and technical/professional schools are at an increased risk of overweight and obesity.


Sedej et al.: Stabilization of Overweight and Obesity in Slovenian Adolescents and Increased Risk in Those Entering Non-Grammar Secondary Schools

\section{Introduction}

Obese children and adolescents are prone to develop overweight or obesity in adulthood which is often associated with various obesity-related health complications [1,2]. Significant obesity-related metabolic and non-metabolic complications may however also present in adolescents and even children [1,3]. Obesity in children represents an important public healthcare problem that will become even more significant in the near future should we not turn the current trends in the prevalence of obesity and its complications $[1,4]$.

Overweight and obesity prevalence was increasing in both developed and developing countries until recently, when it plateaued at an unacceptably high level [5-7]. Increase in prevalence was also reported in Slovenian children and adolescents [8-10]. Recently prevalence of overweight and obesity stabilized in Slovenian 5-year-old children in the period 2001-2009, and in 7-year-old children in the period 1991-2011 in the city of Ljubljana [11, 12]. In the same time period prevalence of overweight and obesity however continued to increase in Slovenian adolescents [13].

The aim of this study was to estimate trends in the prevalence of overweight and obesity in Slovenian adolescents entering secondary schools in the years 2004, 2009, and 2014. In addition, differences in the prevalence of overweight and obesity according to the type of secondary schools adolescents were entering was investigated in the years 2009 and 2014.

\section{Material and Methods}

\section{Subjects}

All students entering secondary schools have an obligatory clinical examination. It is performed by a primary care pediatrician at a local healthcare facility. For the purpose of the study, anonymous data was obtained from primary care pediatricians from all regions of Slovenia that were willing to participate in the study. Data was collected from all adolescents that have had an obligatory clinical examination performed by these pediatricians in the years 2004, 2009, and 2014. In 2014, however, 11 subjects were excluded due to missing data ( 2 gender, 4 height and weight, 5 age). In 2009, 4 subjects were excluded due to missing data ( 3 height, 1 weight), 1 due to age $<15$ years and 51 due to age $>17$ years. In 2004, no subjects were excluded.

The adolescents were measured in their underwear in the morning in a fasted state by a trained medical professional. Height and weight were determined by validated stadiometers and electronic digital scales. Both were rounded to the first decimal place. BMI was calculated as weight (kg) divided by squared height (m).

Overweight and obesity prevalence were calculated using the International Obesity Task Force (IOTF) criteria corresponding to adult's BMI cut-offs of 25 and $30 \mathrm{~kg} / \mathrm{m}^{2}$, respectively, at 18 years of age [14]. These criteria define age- and gender-specific cut-off points from 2- to 18-year-old children.

In 2009 and 2014 data, the type of secondary schools adolescents were entering was also recorded. Adolescents were divided into two groups according to the type of secondary school. Adolescents entering academically oriented grammar secondary schools were included into the first group. Adolescents entering other types of secondary schools - vocational schools and technical/professional secondary schools - were included into the second group. Adolescents with missing data on the type of schooling were excluded from the sub-analysis ( $=1,446$ in 2009 and $N=879$ in 2014). The effective size of the population of students entering secondary schools in Slovenia was obtained for each of the 12 statistical regions and for each gender [15].

\section{Statistical Analysis}

Descriptive statistics were calculated for the three survey time points $(2004,2009$, and 2014). The results were reported as the number and proportion of subjects that were overweight (including obese) or obese, with 95\% confidence interval (95\% CI) separately for males and females.

The gender-specific BMI distributions in consecutive years were compared using quantile-quantile (QQ) plots. QQ plots are scatter plots of the quantiles of one distribution against the quantiles of the second distribution and are useful for the assessment of the similarity between two distributions. If two distributions are similar, the points should be close to the identity line. The BMI distributions were compared using Mann-Whitney test. 
Sedej et al.: Stabilization of Overweight and Obesity in Slovenian Adolescents and Increased Risk in Those Entering Non-Grammar Secondary Schools

To take the sampling scheme into account, the proportion estimates were obtained for each of the statistical regions, and the overall estimate was defined as their weighted average (the weights being the proportion of students effectively enrolled in each region, for each year and gender). To take into account that the sampling fraction was large, a finite population correction was applied; the correction guarantees that the standard errors are estimated correctly when the population is not infinite, and in practice it reduces the standard errors by a factor equal to $\sqrt{ }((\mathrm{N}-\mathrm{n})) /((\mathrm{N}-1))$, where $\mathrm{n}$ and $\mathrm{N}$ are the sizes of the sample and of the population, respectively. Standard errors, $95 \% \mathrm{CI}$, and $\mathrm{p}$ values were based on hypergeometric distribution for the region-specific estimates and on normal approximation for the overall estimates. Unweighted estimates were also derived. The comparisons between vocational and technical/professional schools versus grammar schools were based on unweighted estimates; the p values were obtained using the chi-square test, and the 95\% CI were based on normal approximation.

The R statistical program was used for statistical analysis [16]. The Sprop function included in the sampling book R package was used to obtain the results corrected for the finite population.

\section{Results}

Altogether 17,538 (8,437 females) adolescents entering secondary schools were included in the study. The prevalence of overweight and obesity in the year 2004 has been reported previously [13]. The sample included $10.1 \%$ of all students entering secondary schools in Slovenia in 2004, 31.6\% in 2009, and 40.6\% in 2014. Descriptive statistics data are presented in table 1.

\section{Trends in Overweight and Obesity Prevalence from 2004 to 2014}

There was an increase in the prevalence of overweight in the period 2004-2009, being more profound in males than in females (table 1). It however stabilized in the period 20092014, especially in males (table 1).Obesity prevalence increased significantly from 2004 to 2009 for both females and males, and stabilized in the period 2009-2014 (table 1).

Males were more prone to be overweight than females in the years 2009 and $2014: 8.4$ $(6.4-10.3, \mathrm{p}<0.001)$ versus $5.2(3.5-7.0, \mathrm{p}<0.001)$ (estimated difference of proportions ( $95 \% \mathrm{CI}$, p value)). In addition, males were also more prone than females to be obese in years the 2009 and 2014: 3.6 (2.4-4.8), $\mathrm{p}<0.001$ versus 3.7 (2.7-3.7, $\mathrm{p}<0.001)$.

Similar results were obtained with the unweighted estimates (within 0.5 percentage points for obesity and 1.5 percentage points for overweight, complete data not shown).

\section{Trends in BMI Distribution in Males and Females from 2004 to 2014}

In addition to trends in the prevalence of overweight and obesity, we have also investigated the pattern of BMI distribution within the population. Distribution of central BMI values (mean and median) changed modestly in the selected time period (fig. 1). There was however a change towards an increased prevalence of adolescents with very high BMI values from 2004 to 2009 for both females and males and for males from 2009 to 2014, but not for females (fig. 1). Overall, the 2004 and 2009 gender-specific BMI distributions were significantly different ( $p<0.001$ for both genders), while the 2009 and 2014 BMI distributions were not ( $p=0.72$ and 0.91 for females and males, respectively).

\section{Overweight and Obesity Prevalence in Relation to the Type of Secondary School}

As presented in table 2, the prevalence of overweight and obesity was higher in both males and females attending vocational and technical/professional secondary schools. All differences (for both obesity and overweight within each gender and year) were significant $(\mathrm{p}<0.0001)$. 
Sedej et al.: Stabilization of Overweight and Obesity in Slovenian Adolescents and Increased Risk in Those Entering Non-Grammar Secondary Schools
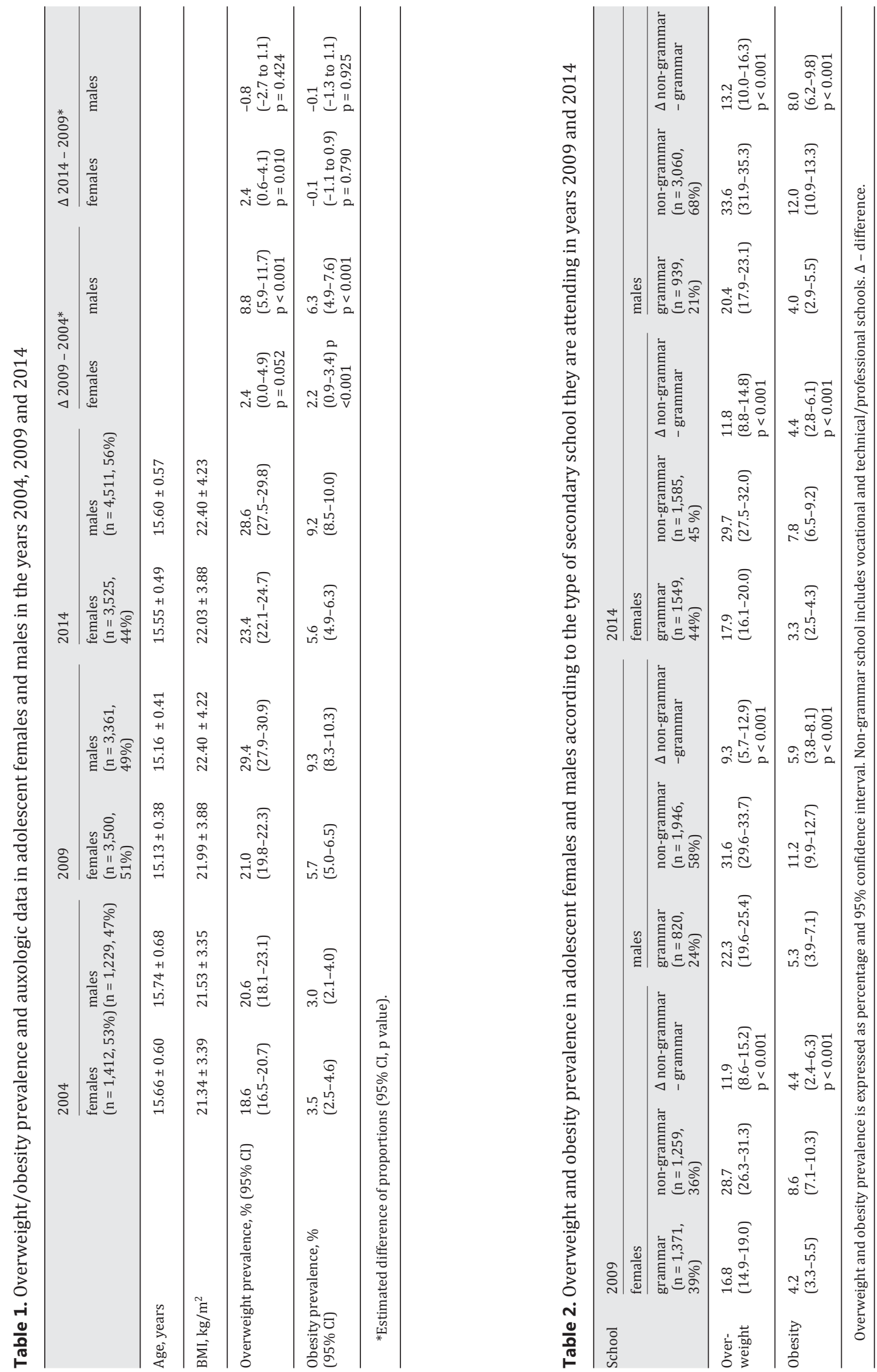
Females: 2004 vs 2009

Males: 2004 vs 2009

BMI - 2004
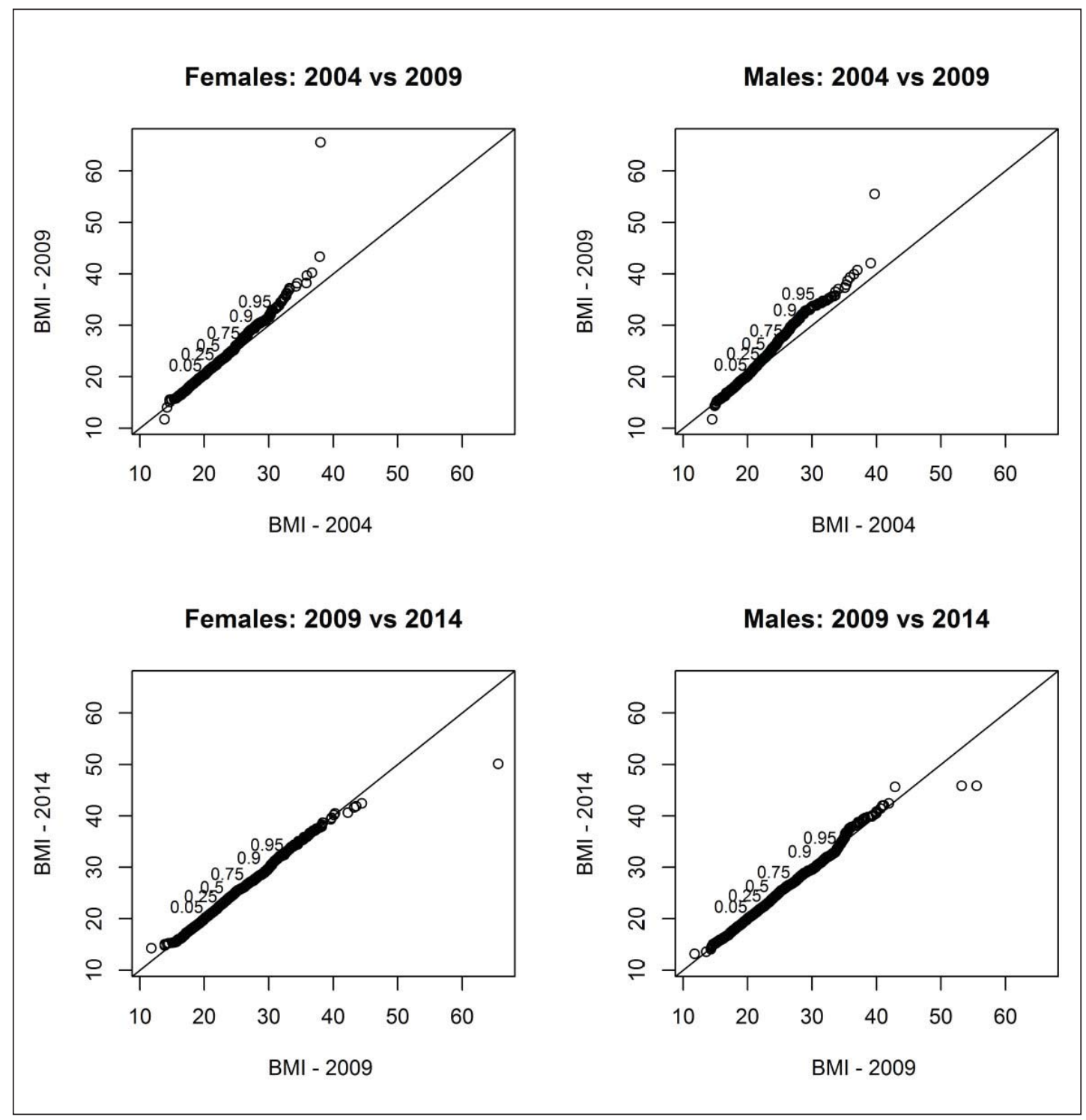

Females: 2009 vs 2014

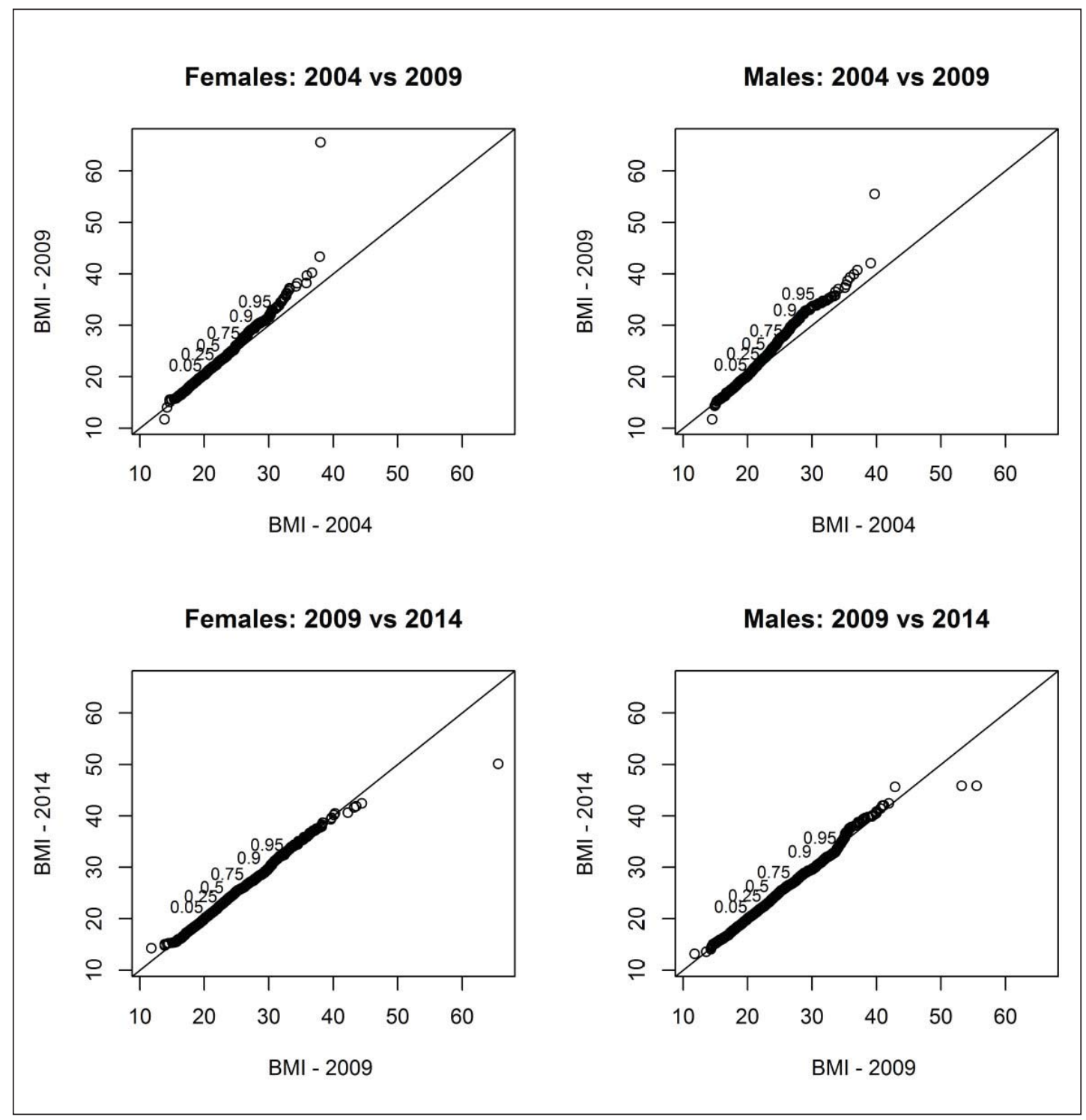

BMI - 2009

Fig. 1. Quantile to quantile plots of observed BMI in adolescent males and females in the period 2004-2014 (pairwise comparisons). The numbers in the plots indicate the ordinate position of the corresponding quantile of the distribution plotted on the ordinate axis, e.g., in the first plot 0.5 is plotted on the ordinate where the median of the distribution of BMI for year 2004 is 21.3.

\section{Discussion}

Trends in overweight and obesity prevalence in Slovenian adolescents entering secondary schools were estimated by analyzing data from $10 \%$ of adolescents entering secondary schools in Slovenia in 2004, 32\% in 2009, and 41\% in 2014 [15]. One of the main findings was that overweight and obesity prevalence increased from 2004 to 2009 (being more profound in males) and then stabilized from 2009 to 2014.

In the time period 2001-2002, Slovenia ranked in the middle of the 34 countries (including several European countries, USA, Canada, and Israel) participating in the Health Behaviour in School-Aged Children (HBSC) survey with an overweight (including obesity) prevalence of 
Sedej et al.: Stabilization of Overweight and Obesity in Slovenian Adolescents and Increased Risk in Those Entering Non-Grammar Secondary Schools

$14.9 \%$ in 10- to 16-year-old adolescents (girls and boys) which was determined using selfreported data [17]. In 2010, according to the IOTF criteria and based on measured weight, $22.5 \%$ of girls and $31.7 \%$ of boys aged $10-12$ years in Slovenia were overweight or obese, which is similar to our results (table 1 ) [18]. Also in 2010, it was estimated that $21.2 \%$ of boys and $13.5 \%$ of girls aged 14 years in the capital city of Ljubljana were overweight according to IOTF criteria [12]. These data are further supported by the data from the HBSC survey performed in the period $2009-2010$ where it was estimated that $13 \%$ of girls and $23 \%$ of boys were overweight or obese. Slovenia ranked in the upper third of countries participating in the study [19].

In the period 2009-2014, however, overweight and obesity prevalence trends in Slovenian adolescents stabilized. Similar trends were recently determined in Germany where overweight and obesity in children/adolescents aged 4-16 years stabilized already in the years 2004 and 2008 [20] and in the USA where obesity in 2- to 19-year-old children remained stable between 2007 and 2008 as well as 2009 and 2010 [21]. In England overweight and obesity prevalence stabilized between 2004 and 2013 in younger children but still increased in 11- to 15-year-old children, although to a lesser extent [22]. Despite the stabilization of overweight and obesity prevalence, Slovenia ranks in the group of countries with the highest prevalence of overweight and obesity in adolescents in Europe [23].

Data on nutritional habits or physical activity of the subjects were unfortunately not collected in the present study. Therefore, we can only speculate on the reasons why the prevalence of overweight and obesity increased in Slovenian adolescents in the period 20042009.

Increased energy intake is suspected to be a major cause for the obesity pandemic in children and adolescents, i.e., a diet high in energy, saturated fats, carbohydrates, sugarsweetened drinks, and low in fiber [24-26]. It was determined that in years 2003-2005 Slovenian adolescents did not meet minimal standards for the intake of vegetables, grains, fish and plant oils, and also fruits in boys [27]. Intake of sugar-sweetened beverages was determined to be extremely high, ranking at the top of international scale of sugar-sweetened beverages intake in 2010 [28]. This was especially evident in boys when compared to girls, possibly explaining the more profound increase in the prevalence of overweight and obesity in adolescent boys when compared to girls in the present study $[27,28]$. It was also estimated that Slovenian adolescents, based on food frequency questionnaire and 3-day weighted dietary protocol, consumed excessive amounts of free sugars, especially in liquid form [29]. Some adolescents did tend to underreport and overreport their energy intake but it was assessed that the assessment of the diet of the whole group was valid [30].

In addition only $44 \%$ of children had regular breakfast during the working week in this time period, which ranked Slovenian adolescents at the very bottom of the international scale of regular breakfast consumption [28]. Having breakfast is associated with higher diet quality and lower prevalence of adiposity [31].

Recently a stabilization of obesity in 5-year-old children in Slovenia was reported. It was speculated that this might be caused by new national nutritional guidelines for the preparation of meals in kindergartens and schools, with decreased total fat and carbohydrate intake [11]. More than $75 \%$ of 5 -year-old Slovenian children visit kindergartens, where they receive up to 4 meals per day [11]. A significantly lower percentage of Slovenian adolescents had regular meals in schools in this time period [32].

In addition to unhealthy diet, physical inactivity is also a major contributor to the development of overweight and obesity in children and adolescents [33-35]. Adolescents from Northern and Central Europe tend to be more physically active than those from Southern Europe, where overweight and obesity prevalence is higher [23, 36]. According to selfreported data from the HBSC study there has been a decline in regular physical activity in 
Sedej et al.: Stabilization of Overweight and Obesity in Slovenian Adolescents and Increased Risk in Those Entering Non-Grammar Secondary Schools

Slovenian adolescents in the period 2002-2010 [28]. A decrease in motor abilities in Slovenian 6- to 18-year-old children and adolescents was determined by objectively measured motor abilities [37]. In addition to nutritional causes this could significantly contribute to the increased prevalence of overweight and obesity in Slovenian adolescents.

Our results indicate that not only the prevalence of obesity but also that of adolescents with very high BMI values increased (fig. 1). This change was more evident in adolescent boys than girls. Similar observations were made in North America, several European countries, Australia, and New Zeeland [21,38-40]. A proposed explanation is that children with a genetic predisposition for obesity are especially susceptible to the environmental risk factors causing obesity, with boys being more sensitive than girls [39].

The prevalence of adolescents that drink sugar-sweetened beverages however decreased in the period 2010-2014. The decrease was more significant in adolescent boys - from $48.8 \%$ in 2010 to $28 \%$ in 2014 , than in girls - from $39.2 \%$ to $22.7 \%$ [28]. This may be attributed to campaigns targeting intake of sugar-sweetened beverages by informing children, parents and educational professionals about negative health effects of sugar-sweetened beverages and advantages of drinking plain water [41]. In addition, the percent of adolescents that regularly eat breakfast increased [28]. Not eating breakfast regularly is associated with higher risk of obesity [31]. On the other side it is possible to decrease this risk by targeted interventions [42]. Regular physical activity plays an prominent role in obesity prevention [35]. In this respect it is important to acknowledge the possible effect of the Healthy Lifestyle Project on the stabilization of overweight and obesity prevalence in Slovenia. This project has been offering children and adolescents aged 6-15 years additional sports activities for several years in all regions of Slovenia [43].

A significantly lower prevalence of overweight and obesity was estimated in adolescents attending grammar schools, compared to those attending secondary vocational and technical/professional schools in the years 2009 and 2014 (table 2). There are limited data on the association between type of school children/adolescents are attending and the overweight and obesity prevalence; however, differences between girls attending secondary grammar schools versus those attending vocational and technical/professional secondary schools were already reported in 2004. At that time girls attending grammar secondary schools were taller, lighter, had smaller skin fold thickness, and achieved better results in motor tests [44]. Children attending secondary vocational schools have poorer academic results when compared to those attending grammar schools. There is a negative association between overweight and obesity prevalence in children and their academic results $[45,46]$. Obese adolescents have higher probability of being enrolled in a school with lower level of education [45]. Academic results are associated with socioeconomic status and directly or indirectly with overweight and obesity. Adolescents attending schools with lower socioeconomic status have a higher BMI when compared to those attending schools with higher socioeconomic status, e.g. private schools [47]. Altogether, overweight and obesity prevalence is associated with adolescent's academic results and socioeconomic status. Therefore specifically targeted interventions, taking into account adolescent's academic and socioeconomic status, need to be strictly implemented for adolescents attending secondary vocational and technical/professional schools in Slovenia.

One of the strengths of the presented study is that a large sample of adolescents from all regions of Slovenia was analyzed. This was especially true for samples from 2009 (32\%) and 2014 (41\%), and thus the main conclusions of the study were derived for the time period 2009-2014. For the sample estimates to be as representative as possible of the population values the proportion estimates were obtained for each of the statistical regions and the overall estimate was defined as their weighted average (the weights being the proportion of students effectively enrolled in each region, for each year and gender). Another strength is 
Sedej et al.: Stabilization of Overweight and Obesity in Slovenian Adolescents and Increased Risk in Those Entering Non-Grammar Secondary Schools

that anthropometric measurements were performed by trained medical professionals using validated stadiometers and electronic digital scales.

Several limitations also have to be acknowledged. The measurements were not limited to one season only, but were performed from September to May of the following year, and this could have an effect on the reported results as it is known that there is a seasonal variability in nutritional status. In addition, data on nutritional and physical activity habits were not collected making a discussion on possible causes of estimated changes and differences in overweight and obesity prevalence speculative. Determination of these causes was however not an aim of the study.

\section{Conclusions}

Overweight and obesity prevalence increased in Slovenian adolescents entering secondary schools in the period 2004-2009. Thereafter, prevalence of overweight and obesity stabilized in the period 2009-2014, similarly to several other developed countries. Adolescent boys seem to be at particularly high risk for developing overweight and obesity, when compared to adolescent girls.

Adolescents entering vocational and technical/professional secondary schools are at an increased risk for overweight and obesity when compared to adolescent entering grammar schools. Specifically targeted intervention, such as healthy and regular meals, regular and appropriate physical activity and educational programs about healthy lifestyle provided by the school, should therefore be strictly implemented, especially in this population.

\section{Acknowledgments}

This study was supported in part by the Slovenian Research Agency grants P3-0343 and J3-6798.

The study protocol was approved by the National Medical Ethics Committee (\#25/10/09). All procedures performed in the study were in accordance with the 1964 Helsinki declaration and its later amendments.

Authors would like to acknowledge the efforts of all primary care pediatricians and their teams that were involved in the collection of the data: Andrenšek Alenka, Cajnkar Kac Miroslava, Dimc Orhideja, Golnar Andreja, Goršič-Frank Mojca, Goste Ksenija, Gracar Irena, Grgič Martina, Gusič Irena, Hočevar Nives, Horvat Alenka, Ivankovič-Kacjan Mojca, Jagrič Friškovec Anita, Jerman Gorišek Lea, Kerin Grošelj Marija, Klemenčič Irena, Klim Janusz, Kocjan Melanja, Kocjan Mirjana, Kodrin Pušnik Janeta, Kolar Božena, Kolman Krapež Irena, Komen Odineja, Kozorog Ksenija, Krajnik Valentič Bernarda, Kržišnik Irena, Kvas Kučič Branka, Laktič Romana, Levstek Plut Maruška, Lovše Eva, Lovšin Salmič Kristina, Miklavič Breda, Orehek-Kirbis Marta, Pečnik Gerlec Miroslava, Petrović Nenad, Rančigaj-Žabkar Marija, Rojko Irena, Schweiger Nemanič Janja, Škulj Aleksandra, Trupac Paola, Vidmar Romič Milena, Žagar Slana Alenka.

K.S. contributed to conception and design of the study, collection of the data, interpretation of the results, and drafting the article. L.L. contributed to analysis and interpretation of data and drafting the article. T.B. contributed to conception and design of the study, collection of the data, interpretation of the results, and critical revision of the manuscript. P.K. contributed to conception and design of the study, interpretation of the results, and critical revision of the manuscript.

\section{Disclosure Statement}

The authors declare that they have no conflict of interest. 


\begin{tabular}{l|l}
\hline Obes Facts 2016;9:241-250 \\
\hline DOI: 10.1159/000445382 & $\begin{array}{l}\text { (c) 2016 The Author(s). Published by S. Karger GmbH, Freiburg } \\
\text { www.karger.com/ofa }\end{array}$ \\
\hline
\end{tabular}

Sedej et al.: Stabilization of Overweight and Obesity in Slovenian Adolescents and Increased Risk in Those Entering Non-Grammar Secondary Schools

\section{References}

1 Cali AMG, Caprio S: Obesity in children and adolescents. J Clin Endocrinol Metabol 2008;93(11 suppl 1):s31s36.

2 Starc G, Strel J: Tracking excess weight and obesity from childhood to young adulthood: a 12-year prospective cohort study in Slovenia. Public Health Nutr 2011;14:49-55.

3 Maggio AB, Martin XE, Saunders Gasser C, Gal-Duding C, Beghetti M, Farpour-Lambert NJ, Chamay-Weber C: Medical and non-medical complications among children and adolescents with excessive body weight. BMC Pediatr 2014;14:232.

4 Farpour-Lambert NJ, Baker JL, Hassapidou M, Holm JC, Nowicka P, O’Malley G, Weiss R: Childhood obesity is a chronic disease demanding specific health care - a position statement from the Childhood Obesity Task Force (COTF) of the European Association for the Study of Obesity (EASO). Obes Facts 2015;8:342-349.

5 Ng M, Fleming T, Robinson M, Thomson B, Graetz N, Margono C, Mullany EC, Biryukov S, Abbafati C, Abera SF, Abraham JP, Abu-Rmeileh NM, Achoki T, AlBuhairan FS, Alemu ZA, Alfonso R, Ali MK, Ali R, Guzman NA, Ammar W, Anwari P, Banerjee A, Barquera S, Basu S, Bennett DA, Bhutta Z, Blore J, Cabral N, Nonato IC, Chang JC, Chowdhury R, Courville KJ, Criqui MH, Cundiff DK, Dabhadkar KC, Dandona L, Davis A, Dayama A, Dharmaratne SD, Ding EL, Durrani AM, Esteghamati A, Farzadfar F, Fay DF, Feigin VL, Flaxman A, Forouzanfar MH, Goto A, Green MA, Gupta R, Hafezi-Nejad N, Hankey GJ, Harewood HC, Havmoeller R, Hay S, Hernandez L, Husseini A, Idrisov BT, Ikeda N, Islami F, Jahangir E, Jassal SK, Jee SH, Jeffreys M, Jonas JB, Kabagambe EK, Khalifa SE, Kengne AP, Khader YS, Khang YH, Kim D, Kimokoti RW, Kinge JM, Kokubo Y, Kosen S, Kwan G, Lai T, Leinsalu M, Li Y, Liang X, Liu S, Logroscino G, Lotufo PA, Lu Y, Ma J, Mainoo NK, Mensah GA, Merriman TR, Mokdad AH, Moschandreas J, Naghavi M, Naheed A, Nand D, Narayan KM, Nelson EL, Neuhouser ML, Nisar MI, Ohkubo T, Oti SO, Pedroza A, Prabhakaran D, Roy N, Sampson U, Seo H, Sepanlou SG, Shibuya K, Shiri R, Shiue I, Singh GM, Singh JA, Skirbekk V, Stapelberg NJ, Sturua L, Sykes BL, Tobias M, Tran BX, Trasande L, Toyoshima H, van de Vijver S, Vasankari TJ, Veerman JL, Velasquez-Melendez G, Vlassov VV, Vollset SE, Vos T, Wang C, Wang X, Weiderpass E, Werdecker A, Wright JL, Yang YC, Yatsuya H, Yoon J, Yoon SJ, Zhao Y, Zhou M, Zhu S, Lopez AD, Murray CJ, Gakidou E: Global, regional, and national prevalence of overweight and obesity in children and adults during 1980-2013:a systematic analysis for the Global Burden of Disease Study 2013. Lancet 2014;384:766-781.

6 Wang Y, Lobstein T: Worldwide trends in childhood overweight and obesity. Int J Pediatr Obes 2006;1:11-25.

7 Wabitsch M, Moss A, Kromeyer-Hauschild K: Unexpected plateauing of childhood obesity rates in developed countries. BMC Med 2014;12:17.

8 Kovač M, Leskošek B, Strel J: Overweight and obesity trends in Slovenian boys from 1991 to 2006. Acta Univ Palacki Olomuc 2008;38:17-25.

9 Leskošek B, Strel J, Kovač M: Overweight and obesity in Slovenian schoolgirls, 1991-2006. Coll Antropol 2010; 34:1303-1308.

10 Kovač M, Jurak G, Leskošek B: The prevalence of excess weight and obesity in Slovenian children and adolescents from 1991 to 2011. Anthropol Notebooks 2012;18: 91-103.

11 Sedej K, Kotnik P, Avbelj Stefanija M, Grošelj U, Širca Čampa A, Lusa L, Battelino T, Bratina N: Decreased prevalence of hypercholesterolaemia and stabilisation of obesity trends in 5-year-old children: possible effects of changed public health policies. Eur J Endocrinol 2014;170:293-300.

12 Kovač M, Jurak G, Zaletelj Kragelj L, Leskošek B: The secular trend in the prevalence of overweight and obesity in the population of primary school children from Ljubljana (Slovenia). Slov J Pub Health 2014;53:188-198.

13 Avbelj M, Saje-Hribar N, Seher-Zupančič M, Brcar P, Kotnik P, Iršič A, Bratanič N, Kržišnik C, Battelino T: Prevalenca čezmerne prehranjenosti in debelosti med pet let starimi otroki in 15 oziroma 16 let starimi mladostnicami in mladostniki v Sloveniji (Prevalence of overweight and obesity among 5 year old children and 15 and 16 year old adolescents in Slovenia). Zdrav Vestn 2005;74:753-59.

14 Cole TJ, Bellizzi MC, Flegal KM, Dietz WH: Establishing a standard definition for child overweight and obesity worldwide: international survey. BMJ 2000;320:1240-1243.

15 Statistični urad Republike Slovenije: Število in delež dijakov in vajencev vpisanih v 1. letnik programov srednješolskega izobraževanja po regijah, Ljubljana, 2015. (Statistical office of Republic of Slovenia: Number and percentage of high school students enrolled in first year of high school by region, Ljubljana, 2015).

16 R Development Core Team: R: A Language and Environment for Statistical Computing. Vienna, the R Foundation for Statistical Computing, 2011.

17 Janssen I, Katzmarzyk PT, Boyce WF, Vereecken C, Mulvihill C, Roberts C, Currie C, Pickett W; Health Behaviour in School-Aged Children Obesity Working Group: Comparison of overweight and obesity prevalence in schoolaged youth from 34 countries and their relationships with physical activity and dietary patterns. Obes Rev 2005;6:123-132.

18 Brug J, van Stralen MM, Te Velde SJ, Chinapaw MJ, De Bourdeaudhuij I, Lien N, Bere E, Maskini V, Singh AS, Maes L, Moreno L, Jan N, Kovacs E, Lobstein T, Manios Y: Differences in weight status and energy-balance related behaviors among schoolchildren across Europe: the ENERGY-project. PLoS ONE 2012;7:e34742.

19 Currie C, Zanotti C, Morgan A, Currie D, de Looze M, Roberts, Samdal O, Smith ORF: Social Determinants of Health and Well-Being among Young People. Health Behaviour in School-Aged Children (HBSC) study: International Report from the 2009/2010 Survey. Copenhagen, WHO Regional Office for Europe, (Health Policy for Children and Adolescents), 2012, pp 115-118. 
Sedej et al.: Stabilization of Overweight and Obesity in Slovenian Adolescents and

Increased Risk in Those Entering Non-Grammar Secondary Schools

20 Blüher S, Meigen C, Gausche R, Keller E, Pfäffle R, Sabin M, Werther G, Odeh R, Kiess W: Age-specific stabilization in obesity prevalence in German children: a cross-sectional study from 1999 to 2008. Int J Pediatr Obes 2011;6:e199-e206.

21 Ogden CL, Carroll MD, Kit BK, Flegal KM: Prevalence of obesity and trends in body mass index among US children and adolescents, 1999-2010. JAMA 2012;307:483-490.

22 Van Jaarsveld CHM, Gulliford MC: Childhood obesity trends from primary care electronic health records in England between 1994 and 2013:population-based cohort study. Arch Dis Child 2015;100:214-219.

23 Grammatikopoulou MG, Poulimeneas D, Gounitsioti IS, Gerothanasi K, Tsigga M, Kiranas E: Prevalence of simple and abdominal obesity in Greek adolescents: the ADONUT study. Clin Obes 2014;4:303-308.

24 Ambrosini GL, Emmett PM, Northstone K, Howe LD, Tilling K, Jebb SA: Identification of a dietary pattern prospectively associated with increased adiposity during childhood and adolescence. Int J Obes 2012;36: 1299-1305.

25 Malik VS, Schulze MB, Hu FB: Intake of sugar-sweetened beverages and weight gain: a systematic review. Am J Clin Nutr 2006;84:274-288.

26 Zheng M, Rangan A, Olsen NJ, Bo Andersen L, Wedderkopp N, Kristensen P, Grøntved A, Ried-Larsen M, Lempert SM, Allman-Farinelli M, Heitmann BL: Sugar-sweetened beverages consumption in relation to changes in body fatness over 6 and 12 years among 9-year-old children: the European Youth Heart Study. Eur J Clin Nutr 2014;68:77-83.

27 Kobe H, Štimec M, Ribič CH, Fidler Mis N: Food intake in Slovenian adolescents and adherence to the Optimized Mixed Diet: a nationally representative study. Public Health Nutr 2012;15:600-608.

28 Jeriček Klanšček H, Koprivnikar H, Drev A, Pucelj V, Zupanič T, Britovšek K: Z zdravjem povezano vedenje v šolskem obdobju med mladostniki v Sloveniji (Health behaviour in school period among adolescents in Slovenia). Ljubljana, National Institute of Public Health of the Republic of Slovenia, 2014

29 Fidler Mis N, Kobe H, Štimec M: Dietary intake of macro-and micronutrients in Slovenian adolescents: comparison with reference values. Ann Nutr Metab 2012;61:305-313.

30 Kobe H, Kržišnik C, Fidler Mis N: Under-and over-reporting of energy intake in Slovenian adolescents. J Nutr Educ Behav 2012;44:574-583.

31 Rampersaud GC, Pereira MA, Girard BL, Adams J, Metzl JD: Breakfast habits, nutritional status, body weight, and academic performance in children and adolescents. J Am Diet Assoc 2005;105:743-760.

32 Statistical Office of Republic of Slovenia: Prebivalec Slovenije poje jabolk in medu več, mlečnih in žitnih izdelkov pa manj kot prebivalec (Inhabitant of Slovenia eats more apples and honey and less milk and grain products than EU inhabitant). EU28, 2014. www.stat.si/StatWeb/glavnanavigacija/podatki/prikazistaronovic o?IdNovice $=6652$ (last accessed July 14, 2016).

33 Chaput JP, Lambert M, Mathieu ME, Tremblay MS, O’ Loughlin J, Tremblay A: Physical activity vs. sedentary time: independent associations with adiposity in children. Pediatr Obes 2012;7:251-258.

34 Ness AR, Leary SD, Mattocks C, Blair SN, Reilly JJ, Wells J, Ingle S, Tilling K, Smith GD, Riddoch C: Objectively measured physical activity and fat mass in a large cohort of children. PLoS Med. 2007;4:e97.

35 Hills AP, Andersen LB, Byrne NM: Physical activity and obesity in children. Br J Sports Med. 2011;45:866-870.

36 Ruiz JR, Ortega FB, Martínez-Gómez D, Labayen I, Moreno LA, De Bourdeaudhuij I, Manios Y, Gonzalez-Gross M, Mauro B, Molnar D, Widhalm K, Marcos A, Beghin L, Castillo MJ, Sjöström M; HELENA Study Group: Objectively measured physical activity and sedentary time in European adolescents: the HELENA study. Am J Epidemiol 2011;174:173-184.

37 Starc G, Strel J, Kovač M: Telesni in gibalni razvoj slovenskih otrok in mladine v številkah: šolsko leto 2007/2008 (Physical and motor development of Slovenian children and adolescents in numbers: school year 2007/2008). Faculty of Sport, University of Ljubljana, Ljubljana, 2010.

38 Ogden CL, Carroll MD, Curtin LR, Lamb MM, Flegal KM: Prevalence of high body mass index in US children and adolescents, 2007-2008. JAMA 2010;303:242-249.

39 Beyerlein A, Toschke AM, von Kries R: Risk factors for childhood overweight: shift of the mean body mass index and shift of the upper percentiles: results from a cross-sectional study. Int J Obes 2010;34:642-648.

40 Bibiloni MDM, Pons A, Tur JA: Prevalence of overweight and obesity in adolescents: a systematic review. ISRN Obes 2013;2013:392747.

41 Fidler Mis N: Projekt zmanjšanje pitja pijač z dodanim sladkorjem pri otrocih, mladostnikih in ogroženih odraslih (Project of decreasing sugar sweetened beverages drinking among children, adolescents and adults at risk). www.vodazmaga.si/wp-content/uploads/2012/10/Oprojektupodrobno.pdf (last accessed July 14, 2016).

42 Ask AS, Hernes S, Aarek I, Johannessen G, Haugen M: Changes in dietary pattern in 15 year old adolescents following a 4 month dietary intervention with school breakfast-a pilot study. Nutr J 2006;5:33.

43 Zdrav življenjski slog 2014-2015 (Healthy lifestyle 2014-2015). www.zsrs-planica.si/zdrav-zivljenjski-slog/ (last accessed July 14, 2016)

44 Kovač M: When social becomes biological: the effect of different physical education curricula on motor and physical development of high-school girls. AnthropolNotebooks 2006;12: 97-112.

45 Do YK, Finkelstein EA: Adolescent weight status and self-reported school performance in South Korea. J Obes 2011;2011:798409.

46 Taras H, Potts-Datema W: Obesity and student performance at school. J Sch Health 2005; 75:291-295.

47 Richmond TK, Subramanian SV: School level contextual factors are associated with the weight status of adolescent males and females. Obesity (Silver Spring) 2008;16:1324-1330. 